\section{British Art in Industry}

ON Friday, January 4, the Prince of Wales opened an Exhibition of British Art in Industry at the Royal Academy, Burlington House. It is to remain open until March 9, and has been organised jointly by the Royal Academy and the Royal Society of Arts. The chief aim of this large-scale experiment is to show the public that British manufacturers of textiles, glassware, furniture, etc., are alive to the importance of consulting artists, when designing their products. The part played by science in rendering it possible to realise this ambition is not referred to nor perhaps could it be within the limited space available at Burlington House. But the scope of the exhibition is wide, and especially striking is the increasing use made of synthetic resins such as bakelite in the manufacture of a great variety of household things. Imperial Chemical Industries, Ltd., show a new form of this colourless plastic material (called Resin M) which it is claimed actually exhibits the sheen found in certain transparent natural crystals, and which can be carved and shaped into many beautiful objects. The glass exhibit, too, is particularly important and interesting. Then there are sets of furnished rooms of modern design, together with a vast display of fabrics, as well as some beautiful jewellery and metal work.

ThE alliance of activities referred to above is assisted by the publication of an abridged account of the aims and work of the Royal Society of Arts, issued by and under the ægis of the Council of the Society, entitled "The Story of the Royal Society of Arts" (London: John Murray, 1935. 3s. 6d.). We read that in 1753 , one William Shipley, residing at Northampton, published certain proposals for raising by subscription a fund for distribution through premiums, for the promotion of improvements in the liberal arts and sciences, manufactures, and so on. Whereupon, in 1754, a Society came into being for the "Encouragement of Arts, Manufactures and Commerce in Great Britain". The organisation had no exact prototype at the time, and was under the obligation (like the later movement elsewhere by Count Rumford), of going forward, or going under. It sueceeded in the former process, and has thus achieved a hundred and eighty years of existence, which, however, have included interludes of vicissitudes. Here we must leave reminiscent records to speak for themselves. But it remains to recall that the Prince Consort became president of the Society of Arts in 1843, and was in office at the time of his death in 1861. Prince Albert's foresight and initiative were of signal value; since his death the interest of our Royal Family has been steadily maintained, strengthened and broadened in recognition of the Society, its aims of the present, and its outlook upon the future.

\section{Eumorfopoulos Collection}

THE announcement by Sir George Hill and Sir Eric Maclagan that the British and Victoria and Albert Museums, assisted by the National Art-Collections
Fund and other donors, have secured the Eumorfopoulos collection for the nation is a source of intense gratification to a wide circle. Not only is the collection of Far Eastern art made by Mr. George Eumorfopoulos the finest in existence, but also the combination of informed taste, opportunity and the necessary financial resources which has made its assembly possible is not likely to recur. The aesthetic, historical and scientific significance of these examples of the artistic activities in every form and material of the peoples of the Far East, and more especially of the Chinese, from the first millennium в.c. onward, has been made widely known by the generosity of its owner, as well as in monographs devoted to the study of specific examples or of classes of objects. In future, a collection of the highest educational value will be available for the instruction of a wider public, more especially if as a whole or in part it should be incorporated in the much desired central Museum of Asiatic Art, which this acquisition may have brought a stage nearer. Nearly one half the purchase money is available to be handed over forthwith to secure the immediate possession of a proportionate part of the collection. An early and ready response to the appeal of Sir George Hill and Sir Eric Maclagan for contributions towards the balance of the cost will be a graceful recognition of the public spirit of the owner in accepting a relatively low figure for what is, in effect, a priceless collection.

\section{Professional Men and Research}

AN address entitled "A Talk about Research" was delivered by Mr. W. P. Elderton to the Institute of Actuaries Students' Society on November 19 and has now been published. The details of the address were highly technical, but the general principles laid down seem to be applicable to any profession, though they are on rather different lines from those suitable for workers in pure science at universities or research institutes. Many young men would like to undertake some kind of research work, but they find it difficult to think of suitable subjects. Of course, a genius would find his own problems and solve them. Leaving aside such, as needing no guidance, some general advice can be given to those less original. One way of starting consists of a study of the history of ideas on a certain subject, taking care to examine French and German sources as well as English. This study will often reveal the inadequate foundation of current theories, and it will then naturally lead on to the attempt to replace the weak portions by something sounder. Another profitable and indeed indispensable task is the reconsideration of the professional practices that were established as the best in the past, in view of the change in contemporary conditions. Mr. Elderton warned his hearers against a hurry to rush into print. They should endeavour to take all possible precautions against error before publication, and to write in good English, so as to be intelligible to any diligent, well-informed reader. Controversy should be avoided, and when they think another writer has made a mistake, they should try to follow his line of thought and consider carefully whether the 
mistake is not their own. The advice of Francis Galton, "Never resent criticism and never reply to it", is good, though hard to follow by those not possessing Galton's saintly disposition and philo. sophical calm.

\section{Statistics and Inductive Inference}

IN a paper read before the Royal Statistical Society on December 18, Prof. R. A. Fisher surveyed the recent change in the outlook of mathematical statisticians. The most profound modification seems to have taken place rather in the logical than in the mathematical aspect, though it has been brought about by the resolution of mathematical difficulties. Statisticians are now dealing with types of uncertain inference wider than those of the theory of probability. Prof. Fisher expressed the view that the current teaching of pure mathematics is not an altogether adequate preparation for fruitful work in this field, for this teaching is purely deductive, omitting the essential concepts of inductive logic, and insists on 'rigour' in a limited sense which he considers very inadequate to the requirements of an inductive problem. The questions raised by Prof. Fisher are of great interest and importance, but it should not be overlooked that there is still some difference of opinion concerning them, as will be seen by a perusal of the series of papers in the Proceedings of the Royal Society (1932-4) by Dr. H. Jeffreys.

\section{Early Man in North America}

Dr. Frank H. H. Roberts, JR., according to a communication issued by the Smithsonian Institution, Washington, D.C., has discovered in the foothills of the Rocky Mountains, in northern Colorado, a habitation site and factory of 'Folsom' man. This discovery is of the greatest importance for American archæology, as not only is it the oldest known habitation site in America, but it is also the first occasion upon which there has been any indication of the mode of life of the peoples by whom the 'Folsom' points were made, beyond the bare fact that they were hunting tribes of a high antiquity -a deduction from the association of these points with the bones of extinct bison, musk ox and mammoth, known to have pastured at the edge of the ice-sheet. The 'Folsom' points, it will be remembered, were first discovered five years ago at Folsom in New Mexico, and since then these finelychipped flint implements have been found, frequently in association with extinct mammals, all over the United States from New Mexico to Virginia and Pennsylvania. It is thought by some authorities that they point to the existence of man in America several thousand years earlier than had previously been supposed. Dr. Roberts's discovery provides something of a cultural background for these scattered finds. The site he has now discovered rests upon a hard, chalk-like formation with about fifty feet of alluvial deposits above it. These must have been laid down very slowly. It is about a quarter of a mile in extent, but as yet only a small part has been excavated. The relics represent several camp sites occupied over a period of years. Flint nodules from which the implements were manufactured are plentiful. Thirty characteristic points and a great variety of scrapers, rough stone blades, drills, engraving tools and hammerstones, with a large number of broken animal bones, have been collected.

\section{Antiquity}

WrтH its December issue, Antiquity completes its eighth year. The editor of the only free-lance journal entirely devoted to archæological matters is to be congratulated on his success in having carried through this enterprise successfully and without the assistance of any official organisation, in a period of exceptional difficulty. While there is undoubtedly a considerable public which is interested in archæological discovery up to a point, to hold that interest requires both tact and judgment. The editor, whose aim is to present to his readers scientifically sound and accurate information of the latest movements in archæological discovery in a popular form, has a difficult course to steer, if he is to avoid the appeal to the sensationalism which flavours the news of 'finds' as it appears in most of the daily Press. On the other hand, the editor of Antiquity, both by his own 'tilting' in his unconventional notes and otherwise, encourages his contributors to an engaging freedom of treatment which in itself adds no little attraction to the pages of his periodical. The contents of Antiquity of December illustrate these qualities admirably. If, for example, Mr. Noel Myres' criticism of Dr. Mortimer Wheeler's article in a previous issue on the topography of Saxon London ventilates further a subject which is of perennial interest to a wide circle, Dr. Wheeler's reply will appeal equally to those who appreciate learning worn lightly. Among the remaining contents of this issue, which are as a whole no less attractive, it is, perhaps, permissible to refer to the contribution by Sir George Macdonald on the Romans in the Middle East, which is an illuminating commentary on M. A. Poidebard's recently published air survey of the Roman frontier in Syria. Like its predecessors, this issue fully supports the editor's appeal for an extended circulation to ensure the continued existence of a publication which is doing excellent work for archæological science by keeping its achievement before a wider public than is reached through channels of a more formal nature.

\section{Thermo-remanence of Bricks}

A LETTER has been received from Mr. T. G. Bocking, Princes Chambers, 6 Corporation Street, Birmingham, 2, giving an account of some observations on the magnetic properties of bricks. Bricks were selected from a number of South Staffordshire kilns, the direction in which the bricks were lying when baked being noted. The polarity was most clearly marked when the bricks had been lying in a north-south direction, and it was found that the bricks were magnetised approximately along the line of magnetic dip. Among the bricks examined were 